\title{
Boards of directors and organizational ambidexterity in knowledge-intensive firms
}

\author{
Jana Oehmichen, Mariano L. M. Heyden, Dimitrios Georgakakis \& Henk W. \\ Volberda
}

To cite this article: Jana Oehmichen, Mariano L. M. Heyden, Dimitrios Georgakakis \& Henk W. Volberda (2016): Boards of directors and organizational ambidexterity in knowledge-intensive firms, The International Journal of Human Resource Management, DOI: 10.1080/09585192.2016.1244904

To link to this article: http://dx.doi.org/10.1080/09585192.2016.1244904

Published online: 26 Oct 2016.

Submit your article to this journal $\llbracket$

View related articles $\nearrow$

View Crossmark data $\nearrow$ 


\title{
Boards of directors and organizational ambidexterity in knowledge-intensive firms
}

\author{
Jana Oehmichen ${ }^{a}$, Mariano L. M. Heyden ${ }^{b}$, Dimitrios Georgakakis ${ }^{c}$ and \\ Henk W. Volberdad \\ aChair of Management and Control, Georg-August-University Göttingen, Goettingen, Germany; \\ bInternational Business \& Strategy Discipline Group, Newcastle Business School, Newcastle, Australia; \\ 'Research Institute for International Management, University of St. Gallen, St. Gallen, Switzerland; \\ dDepartment of Strategy \& Entrepreneurship, Rotterdam School of Management, Erasmus University, \\ Rotterdam, Netherlands
}

\begin{abstract}
We examine the relation between boards of directors' knowledge heterogeneity and organizational ambidexterity (OA) (i.e. simultaneous exploration and exploitation) in knowledge-intensive firms (KIFs). Although the literature on OA has started to emphasize its antecedents, the role of the board remains unaddressed. This is an important omission, as boards have become increasingly involved in strategy-making. In turn, studies on boards have looked at their influence on either exploration- or exploitation-type strategies. Yet, KIFs particularly need to balance both exploration and exploitation to renew their knowledge base. We draw on knowledgebased perspectives to disentangle the benefits and costs of board knowledge heterogeneity for driving OA in KIFs. Our empirical analysis based on a longitudinal panel of UK pharmaceutical firms provides support for our hypothesized U-shaped relation. Our findings suggest that the benefits of knowledge heterogeneity only outweigh the costs beyond a particular threshold. Overall, our theoretical approach and allied findings advance the literature by introducing boundary conditions to the resource provision role of boards in KIFs. We discuss contributions for organizational learning, strategic leadership, and human resource management. We conclude with implications for theory and practice, as well as key opportunities for future research.
\end{abstract}

\section{KEYWORDS}

Ambidexterity; boards of directors; content analysis; heterogeneity; knowledge-intensive firms; pharmaceutical industry

\section{Introduction}

Knowledge is considered the defining source of competitive prowess of our generation (Grant, 1996). Accordingly, knowledge-intensive firms (KIFs) have featured as key drivers of global economic growth (Alvesson, 1993; Von Nordenflycht, 
2010). Yet, intensifying global competition has diminished the returns to the established knowledge base of KIFs. Increasingly, profitable product lines are reverse-engineered and replicated at lower cost (Lieberman \& Asaba, 2006), highskilled/low-cost global players capture fast-emerging markets (Luo et al., 2011) and variable intellectual property regulations in global markets impair KIF's ability to secure returns on their proprietary knowledge (Cohen \& Kaimenakis, 2007). To compete in today's global business arena, KIFs need to renew their knowledge base by continuously exploring new knowledge for developing innovative products and services, while simultaneously exploiting their established competencies to improve current offerings.

Exploration and exploitation are two fundamental organizational learning strategies to renew the knowledge base of the firm (March, 1991). Exploration strategies are supported by behaviors such as risk-taking, opportunity-seeking, experimentation, and innovation. Exploration tends to have a more long-term and uncertain payoff structure, but helps rejuvenate the knowledge base of the firm. Exploitation in turn is fueled by incremental fine-tuning, variance-reduction, and efficiency-seeking behaviors. Returns to exploitative strategies tend to be more predictable in the short term, but the supporting activities reduce adaptability by reinforcing the established knowledge base. Given the different payoff structures of these learning strategies, scholars have shown that firms that are dexterous at both learning strategies tend to be more innovative, globally competitive, and improve their chances of long-term survival (Piao, 2010). However, due to the paradoxical nature of these activities, organizations often over engage in one at the expense of the other (Levinthal \& March, 1993), often to their own detriment (Wang \& Li, 2008).

Bustling literature on organizational ambidexterity $(\mathrm{OA})$ has sought to examine the mechanisms through which firms can simultaneously explore and exploit (see O’Reilly \& Tushman, 2013; Raisch \& Birkinshaw, 2008; Simsek, 2009; Turner, Swart, \& Maylor, 2013 for overviews of this literature). Early studies established the case for the importance of OA by emphasizing its outcomes (e.g. He \& Wong, 2004). More recently, academic discourse has shifted to the antecedents of OA at the industry (e.g. Jansen, Van den Bosch, \& Volberda, 2005), firm (e.g. Jansen, van den Bosch, \& Volberda, 2006), business unit (e.g. Yitzhack Halevi, Carmeli, \& Brueller, 2015), and senior manager level (e.g. Jansen, George, Van Den Bosch, \& Volberda, 2008). Notably absent from this discussion, however, is the board of directors. This is a key omission, as the board of directors represents the highest level of strategic leaders entrusted with safeguarding the well-being of the organization (Forbes \& Milliken, 1999; Triana, Miller, \& Trzebiatowski, 2014). Addressing this gap, we seek to introduce the board of directors as an important, yet previously omitted, antecedent of OA. We seek to offer several contributions with our approach.

First, we contend that the board is an important micro-foundational antecedent of KIFs' ability to pursue both exploration and exploitation (Polanyi, 1966; 
Starbuck, 1992). We build on studies showing that boards have become more actively involved in strategy-making by setting strategic priorities, contributing heterogeneous knowledge resources from outside the firm, and defining the scope of task-discussions (Hendry, Kiel, \& Nicholson, 2010; Mínguez-Vera \& Martin, 2011). Although literature on OA has started to address the influence of other strategic leaders, such as senior (e.g. Yitzhack Halevi et al., 2015) and middle managers (e.g. Burgess, Strauss, Currie, \& Geoffrey, 2015; Chang \& Hughes, 2012), to our knowledge, only two studies have looked at the link between boards and exploration/exploitation more generally (Heyden, Oehmichen, Nichting, \& Volberda, 2015; Walrave, van Oorschot, \& Romme, 2011). Advancing this nascent sub-stream of inquiry into $\mathrm{OA}$, we add that boards of directors play a distinctive role in shaping the extent to which exploration and exploitation are integrated in strategy. Incorporating boards ultimately helps us advance a more comprehensive picture of how strategic leaders across the hierarchy influence OA (Bledow, Frese, Anderson, Erez, \& Farr, 2009; Simsek, 2009).

Second, we contribute by proposing and testing a U-shape association between board knowledge heterogeneity and OA. Highlighting the complex nonlinear link between boards and OA is an important contribution, as previous studies have only examined how the board influences either exploratory or exploitative strategies. For instance, board heterogeneity has been associated with exploratory types of strategic outcomes such as new market entry decisions (Diestre, Rajagopalan, \& Dutta, 2015), entrepreneurial focus (Tuggle, Schnatterly, \& Johnson, 2010), and strategic change (Haynes \& Hillman, 2010). Board characteristics have also been linked to exploitation type outcomes such as downsizing decisions (Yawson, 2006), divestiture intensity (Hoskisson, Johnson, \& Moesel, 1994), and restructuring (Abor, Graham, \& Yawson, 2011). Our theorized U-shape association between board knowledge heterogeneity and OA allows us to consolidate these findings by unearthing threshold effects in the relation between board composition and $\mathrm{OA}$.

Third, although studies often emphasize the benefits of knowledge heterogeneity of boards (Heyden, Oehmichen, et al., 2015; Tuggle, Schnatterly, \& Johnson, 2010), we add nuance to these insights by co-theorizing the 'costs' of integrating knowledge across heterogeneous functional boundaries (Bechky, 2003; Carlile, 2002, 2004). In particular, although the board's heterogeneous knowledge resources can improve the quality of decisions (McDonald, Westphal, \& Graebner, 2008), expand the richness of solutions developed (Jackson, 1992), and increase comprehensiveness of short-term and long-term issues covered (Tuggle et al., 2010), combining heterogeneous knowledge often incites conflict, slows decision speed, and increases polarization in decision behaviors (Nielsen \& Nielsen, 2013). Our study provides important insights into both costs and benefits of knowledge heterogeneity of the board and allows us to inform scholars and practitioners on the implications of board-level configurations in KIFs. 


\section{Conceptual background and hypothesis}

\section{OA in knowledge-intensive firms}

'Knowledge intensity indicates that production of a firm's output relies on a substantial body of complex knowledge' (Von Nordenflycht, 2010, p. 159). To leverage this complex knowledge, KIFs are characterized by particular human capital needs (Swart \& Kinnie, 2003b), features of innovation processes (Swart \& Kinnie, 2003a), and structural arrangements (Jansen, Tempelaar, Van den Bosch, \& Volberda, 2009). These interrelated properties pose particular demands for integrating simultaneous exploitation and exploration at the highest level of strategy.

The human capital needs are driven by the fact that work in KIFs is highly intellectual in nature (Alvesson, 2000; Swart \& Kinnie, 2003b). Knowledge workers have a strong need for autonomy (Von Nordenflycht, 2010) and KIFs need to prescribe boundaries to achieve strategically aligned behaviors (Mom, Van den Bosch, \& Volberda, 2009), while at the same time stimulating the autonomy necessary for fresh ideas that challenge the status quo (Burgelman, 1983). Their innovation process in turn requires explorative mechanisms to identify and support promising new products (Vassolo, Anand, \& Folta, 2004), while simultaneously having exploitative filters to terminate unsuccessful product streams and avoid escalation of commitment (Boulding, Morgan, \& Staelin, 1997). Structurally, KIFs rely on an intricate mix of coordination mechanisms to manage cross-functional knowledge across hierarchical interfaces (Mom, Van den Bosch, \& Volberda, 2007). Therefore, KIFs need structures that are sufficiently formalized as to gain exploitation benefits (Jansen et al., 2006), as well as sufficiently flexible to explore knowledge recombination opportunities across functional domains (Jansen et al., 2009).

As the aforementioned characteristics of KIFs coexist in intricate ways and have long-term implications for the well-being of the organization, how they are consolidated in organizational strategy requires input and approval from their boards of directors.

\section{Boards of directors and $O A$}

Boards function as a mechanism for aligning the organization with its environment at the highest level of strategy (Boyd, 1990). Boards bring new and valuable tacit knowledge to strategy through the functional expertise of non-executive directors as they 'inform firm strategy with insights about opportunities and threats residing in blind spots (e.g. changing consumer preferences), assist in identifying weak signals in the environment (e.g. emerging technologies), act as early-warning system for imminent changes (e.g. regulatory), and provide assessments and judgments of best practices. (e.g. new ways of working)' (Heyden, Oehmichen, et al., 2015, p. 156). However, knowledge heterogeneity has been shown to have both benefits and costs. 


\section{Upsides of board knowledge heterogeneity for OA}

Studies have shown that heterogeneity in characteristics of boards is crucial for understanding how their knowledge resources influence strategy (Minichilli, Zattoni, \& Zona, 2009). Boards embody tacit knowledge accumulated through the dominant expertise of their directors in different organizational functions (Heyden, Oehmichen, et al., 2015). Heterogeneity in functional expertise of the board has particularly been shown to enable boards to provide the firm with broader expertise, perspectives, and skills (Zoogah, Vora, Richard, \& Peng, 2011).

Board knowledge resources stemming from expertise in organizational functions can be classified into two higher order dimensions of task orientations (Hambrick \& Mason, 1984). 'Output' orientations stem from expertise in domains such as marketing, sales, and product R\&D that focus attention on growth, customer demands, and emphasize the search for new market opportunities 'Throughput' orientation follows from experience in functions such as production, process engineering, and accounting where the emphasis is on the internal organization and on improving how the organization turns inputs into output. An output-oriented emphasis ensures that opportunities for growth are taken into account (exploration), whereas throughput orientation ensures that efficiency is not disregarded (exploitation).

Board functional knowledge heterogeneity compels members to undertake more in-depth discussions and more elaborate decisions. As a result, more heterogeneous groups tend to devise multiple viable solutions for the same issue (Heyden, van Doorn, Reimer, Van Den Bosch, \& Volberda, 2013). Dealing with multiple issues simultaneously improves cognitive processing and allows the group to integrate a more varied range of possible solutions (Judge \& Miller, 1991). From the aforementioned interpretation, functionally heterogeneous boards can be expected to be more inclined to prioritize simultaneous consideration of longand short-term issues, while also being more adept at coming up with diverse solutions to creatively synthesize the contradictory demands of exploration and exploitation.

\section{Downsides of board knowledge heterogeneity for OA}

The heterogeneous functional knowledge that boards embody is largely tacit. As a result, deeply rooted assumptions only become evident as members engage in task discussions and are forced to elaborate and clarify their distinctive beliefs to dissimilar others. These disclosures highlight the different perspectives of each board member concerning the content and timeline of issues that need to be prioritized (Triana et al., 2014). Indeed, functional heterogeneity may inhibit internal task processes within a team due to different thought worlds (Dougherty, 1992) and can translate into communication problems, interpersonal conflicts, high turnover in the group, and reduced willingness to cooperate (Ali, Kulik, \& Metz, 2011). Heterogeneity is thus often associated with interactional difficulties and reduced levels of behavioral integration (Milliken \& Martins, 1996). 
In addition, heterogeneous teams tend to be slower in their decision-making (Hambrick, Cho, \& Chen, 1996), which can limit 'the board's ability to take timely strategic action' (Goodstein, Gautam, \& Boeker, 1994, p. 246). Yet, strategic decisions are often uncertain and decision-makers have to adjust swiftly by incorporating performance feedback (Sterman, 1989). Slower decision-making reduces the frequency of performance feedback, making it more difficult for decision-makers to counterbalance tendencies towards over-exploration or overexploitation in a timely fashion (Lungeanu, Stern, \& Zajac, 2016; Maslach, 2016). Indeed, evidence suggests that short cycles of performance feedback, as a result of swift decision-making, can accumulate into a better balance of long- and shortterm decisions (Ben-Oz \& Greve, 2012), while simultaneously improving the quality of exploratory (e.g. forward-looking patents; Khanna, Guler, \& Nerkar, 2016) and exploitative (e.g. restructuring; Vidal \& Mitchell, 2015) decisions.

\section{Consolidating effects of board knowledge heterogeneity on OA}

The literature on knowledge coordination has highlighted that cross-functional groups often incur coordination costs without achieving the prospective benefits (Ben-Menahem, von Krogh, Erden, \& Schneider, 2016; Majchrzak, More, \& Faraj, 2012). Indeed, groups may face several challenges at differing degrees of heterogeneity. When groups have low to moderate levels of heterogeneity, they are likely to come up with a more restricted, but more polarized, set of solutions (Heyden et al., 2013; Lau \& Murnighan, 1998). Polarized viewpoints can negatively affect the quality of decisions, as members search and emphasize information that reinforces their preferred positions, thus further dividing the group (van Knippenberg, De Dreu, \& Homan, 2004). Hence, groups with moderate levels of heterogeneity either have difficulties to reach true consensus (Knight et al., 1999) or engage in consensus-seeking behaviors by basing decisions on mutually shared knowledge while omitting dissenting information (van Ginkel \& van Knippenberg, 2008). As a result, the negative aspects of diverse knowledge mentioned above are more likely to occur at low to moderate levels of heterogeneity.

In turn, the beneficial aspects of heterogeneity are likely to occur at high levels of board heterogeneity. Although highly heterogeneous boards sometimes struggle to exchange and integrate knowledge across domains of expertise (Cannella, Park, \& Lee, 2008), these differences drive them to elaborate and explain their distinctive perspectives and viewpoints when there is minimal overlap in functional understandings (i.e. high heterogeneity; van Knippenberg et al., 2004). Highly heterogeneous teams have 'few common bases for subgroup formation and social identity are likely to exist in [decision-making] groups with relatively high levels of diversity' (Richard, Barnett, Dwyer, \& Chadwick, 2004, p. 256). This results in more information elaboration and richer discussions (Bezrukova, Jehn, Zanutto, \& Thatcher, 2009), while also increasing the speed of cognitive processing (Judge \& Miller, 1991), as members expand their cognitive frames to accommodate new insights from those with knowledge that is different from their own. 
We suggest that board heterogeneity will have a nonlinear effect on OA. As heterogeneity increases from low to moderate degrees, conflict and disintegration challenges will constrain moderately heterogeneous boards to benefit from the variety of knowledge of dissimilar members. As such, the costs will outweigh the benefits of heterogeneity (Harrison \& Klein, 2007). However, as levels of heterogeneity increase beyond the moderate threshold, board members are forced to develop synthesizing mechanisms through which they create a new common ground that incorporates discrepant insights. For example, as heterogeneity levels move from moderate to high, group members will learn to recognize the bounds of each other's distinctive knowledge by establishing bounds of who knows what (Heavey \& Simsek, in press; Mell, van Knippenberg, \& van Ginkel, 2014; Zhang, Hempel, Han, \& Tjosvold, 2007), which allows members to dissect complex problems in more digestible bits.

Acknowledging and recognizing knowledge boundaries in the group allows highly heterogeneous boards to overcome potential subgroup formation and incorporate different perspectives to the task problem at hand, mitigating disruptive conflict and increasing the efficiency of processing of distributed information. In this range, the benefits of knowledge heterogeneity for OA become increasingly realized through more dexterous interpretations of strategy, as boards devise more creative solutions to integrate the paradoxical demands of exploration and exploitation. On this basis, we argue that highly heterogeneous boards will be better able to synthesize the diverse knowledge in exploring and exploiting organizational resources. Accordingly,

Hypothesis: There will be a U-shaped relationship between board functional knowledge heterogeneity and OA.

\section{Data and definition of variables}

\section{Sample and research design}

We tested our hypothesis on a longitudinal panel of publicly listed UK pharmaceutical firms from 2005 to 2009. Pharmaceutical companies are KIFs with large economic implications (Coff, 1999). Work in pharmaceutical companies is of highly intellectual nature (Alvesson, 2000; Swart \& Kinnie, 2003b) and most workers have to be well educated and qualified (Swart \& Kinnie, 2003b). These companies also engage actively in discovery and patenting activities (Khanna et al., 2016) and also have intricate global structures (Hess \& Rothaermel, 2011). In 2009, the European pharmaceutical industry accounted for $30.6 \%$ of global pharmaceutical sales according to the consultancy firm Pharma Strategy Group, compared with $39.8 \%$ for North America of a total market value around 700 billion US\$ and CAGR of 7\% between 2005 and 2010. Our data-set includes all publicly listed companies in the United Kingdom within the ' 21 '-sector of the NACE Rev. Two classification systems are used in the European Union to classify economic 
activities. This classification is comparable to the '283' sector of the Standard Industrial Classification of the United States. Looking at the pharma industry in the UK is also appropriate, as UK firms are characterized by a one-tier board model, which has been shown to be a crucial condition for boards to influence strategy (Heyden et al., in press).

\section{Data and measures}

\section{Organizational ambidexterity}

As we have conceptualized ambidexterity as the simultaneous pursuit of exploration and exploitation in strategy, we operationalized $\mathrm{OA}$ as the multiplicative of exploration and exploitation, consistent with recent studies (e.g. Cao, Gedajlovic, \& Zhang, 2009; Jansen, Simsek, \& Cao, 2012; Mom, Fourné, \& Jansen, 2015). We followed the operationalization of Heyden et al. (in press) to obtain separate scores for both exploration and exploitation first. This approach is based on a computeraided text analysis of corporate documents (e.g. annual reports) and builds on an increasingly established approach to capture exploration and exploitation (e.g. Uotila, Maula, Keil, \& Zahra, 2009; Volberda, Baden-Fuller, \& Van den Bosch, 2001). As annual reports tend to comprise the most comprehensive overview of issues emphasized in the organization's strategy and can reliably be compared across firms and over time ((Heyden, Sidhu, \& Volberda, in press), we drew on the full textual input from annual reports corresponding to the firm-year observations in our sample. This approach is consistent with innovative developments in the broader field of strategic leadership to measure different aspects of strategy, such as the focus on entrepreneurial issues in strategy (e.g. Tuggle et al., 2010) and management innovation (Heyden, Sidhu, et al., in press).

We applied the validated dictionary of Heyden et al. (2015), which expanded and contextualized the search terms of March (1991), as applied in Uotila et al. (2009). Importantly in this operationalization is a contextually appropriate interpretation of exploration and exploitation in our empirical setting. In particular, Heyden et al. (2015, pp. 161-162) contextualized exploration in the European pharmaceutical industry as embracing activities such as the development of products (drugs, devices), services, and technologies, the entering of markets that are new to the firm, or a combination of both. Exploitation in this setting was contextualized as capturing activities like optimization, rationalization, and fine-tuning of existing drugs, services, and technologies for existing customers and families of drugs. The search dictionary is presented in Table 1.

\section{Board knowledge heterogeneity}

We operationalized board members as the group of non-executive directors for the UK. Membership to the boards was based on the directors listed in Boardex. Information of individual directors was aggregated using Blau's index. Blau's index is a function of the proportion $(P)$ of members of the board in the $k$ th category 
Table 1. Search dictionary for content analysis.

\begin{tabular}{|c|c|}
\hline Exploitation in European pharmaceutical industry & Exploration in European pharmaceutical industry \\
\hline $\begin{array}{l}\text { Exploit*, Certain*, Fast, React*, Refine*, Certification, } \\
\text { Formalization, Reduction_of_costs, Cost_reduction, } \\
\text { Choice, Clarity, Reliab*, Codification, Improv*, Restyl*, } \\
\text { Efficiency, Commercial_alliance, Incremental_inno- } \\
\text { vation*, Result_based_objective, Select*, Continu*, } \\
\text { Local search, Routin*, Implement*, Control*, Modu- } \\
\text { lar_production, Rules, Directives, Execute, Correct*, } \\
\text { Operational_strateg*, Serial_production, Accelerat*, } \\
\text { Customer_loyalty, Perfect*, Short_term, Adaption*, } \\
\text { Deep_background, Planning, Shorten, Adjust*, } \\
\text { Defend*, Practicality, Stabil*, Applied_research, Dif- } \\
\text { ferentiat*, Precision, Standard*, Automat*, Execution, } \\
\text { Predictability, Up-date, Aversion_to_risk, Proce- } \\
\text { dure, Variant*, Bureaucr*,Programm*, Verification, } \\
\text { Caution*, Existing, Prudence, Low_cost, Centraliz*, } \\
\text { Rational*, Inertia, Shareholder_value, Short_run, } \\
\text { Short_time_horizon, Speed, Proxim**,Current, } \\
\text { Extens* }^{*} \text {, Blockbuster_revenue, Optimize, Streamline }\end{array}$ & $\begin{array}{l}\text { Explor* Chang*, Freedom, Patent, Search*, Creative, } \\
\text { Idea, Proactiv*, Variation*, Decentral*, Innovat*, } \\
\text { R\&D_alliance, Invent*, Development_programme*, } \\
\text { Research_development, Experiment*, Discontin*, } \\
\text { Long_term, Release, Play, Distant*, Low_codifica- } \\
\text { tion, Revolution*,Flexib*, distant_search, Low_- } \\
\text { formalization, Slow_learning, Discover*, Diversif*, } \\
\text { Low_standardization, Something_extra, Dynamic*, } \\
\text { New, Spirit_of_initiative, Adventur*, Evolution*, } \\
\text { Start_Up, Anticipat*, Expand*,Tacit_knowledge, } \\
\text { Astound*, Transform*, Autonom*, Fantasy, Uncer- } \\
\text { tain*, Being_the_first, Far_beyond, Novel*, Vary, } \\
\text { Break*_away, Forefront, Open_mentality, Wide_- } \\
\text { background, Diffus*, Long_run, Long_time_horizon, }^{*} \text {, }{ }^{*} \text {, } \\
\text { Adapt*, Stakeholder_value, Stress, Collaboration, } \\
\text { Cooperation, Strength*_Pipeline, Expans*, Reposi- } \\
\text { tion*, Licensing, R\&D_Outsourc* }\end{array}$ \\
\hline
\end{tabular}

(Harrison \& Klein, 2007) and is formally defined $1-\sum P k^{2}$. We operationalized knowledge heterogeneity as proxied by board functional experience heterogeneity. We coded heterogeneity in predominant functional experience attributes along eight categories $(1=$ production and operations; $2=\mathrm{R} \& \mathrm{D}$ and engineering; $3=$ accounting and finance; $4=$ management and administration; $5=$ marketing and sales; 6 law; 7 = personnel and labor relations; $8=$ other). This information was hand collected from publicly available sources. Index scores were only included when at least $75 \%$ of complete information was available.

\section{Control variables}

We controlled for board, firm, and ownership effects by adding the following variables to our multivariate analyses. To control for general board effects we included the natural logarithm of board size and the board members average tenure. The variables educational heterogeneity, age heterogeneity, tenure heterogeneity, and gender, controlled for additional board heterogeneity effects. We measured educational heterogeneity as the Blau index of board members highest education (Georgakakis \& Ruigrok, in press; Nielsen \& Nielsen, 2013), age and tenure heterogeneity with the respective coefficient of variation of age and tenure. Gender is coded as the percentage of female board members. Firm level controls include firm size, measured as the natural logarithm of the number of employees and firm age measure as natural logarithm of the number of years since foundation. Furthermore, we added financial leverage, return on assets as a measure of performance, and research and development investments. To control for firms' corporate governance structure beyond their board composition, we used the following two ownership variables: the percentage of stock owned by institutional investors and the percentage of stock owned by strategic investors. Board data 
were hand collected, while Datastream and ThomsonOne were consulted for firm and ownership data.

\section{Analysis and results}

We analyzed the data using Generalized Estimating Equations. This multivariate technique is suitable in the event of non-independent observations and has been considered an emerging best practice in quantitative management research, as it accounts for both time-invariant 'subject' effects and auto-correlated, time-varying, 'within-subject' effects (Ballinger, 2004). This technique has further demonstrated its usefulness and versatility for longitudinal data structures commonly used in the broader strategic leadership literature (e.g. Chatterjee \& Hambrick, 2007). We specified firm subject effect and treated the repeated annual observations as within-subject effects. Model fit was assessed based on the level and significance of the Wald's chi-square and QIC statistics (Pan, 2001).

\section{Multivariate results}

Descriptives and correlations of all variables used are highlighted in Table 2. Our results in Table 3 support our hypothesis of the U-shaped relationship between board functional knowledge heterogeneity and OA. Additionally, the highest variance inflation factor is 7.32, well below the tolerated threshold of 10 (Hair, Anderson, Tatham, \& Black, 1998). As Model 1 in Table 2 indicates, we do not find a significant linear effect of board functional knowledge heterogeneity on OA. However, the negative and significant coefficient of the linear term and the positive significant coefficient of the squared term allude to a nonlinear effect. To examine this, we followed the latest recommendations in the methodological literature and plotted our results (Haans, Pieters, \& He, 2016). Figure 1 indeed depicts a U-shaping association, corroborating our hypothesis of a nonlinear U-shaped relationship between board functional knowledge heterogeneity and OA.

\section{Discussion}

In this study, we have examined the link between board of director knowledge heterogeneity and OA. We first briefly outlined the importance of OA for the specific strategic needs of KIFs, which has previously not been addressed. Next, we drew on the knowledge-based view that primarily accentuates heterogeneity's benefits and research on knowledge coordination that has emphasized potential costs. As the sharing of knowledge is of special importance in KIFs (Swart, Kinnie, van Rossenberg, \& Yalabik, 2014), we expect the heterogeneity of knowledge on the board to have a significant impact on strategy. Although heterogeneity can be expected to be beneficial for the quality of decisions (McDonald et al., 2008), it also has costs that can undercut its potential benefits. Integrating these streams 


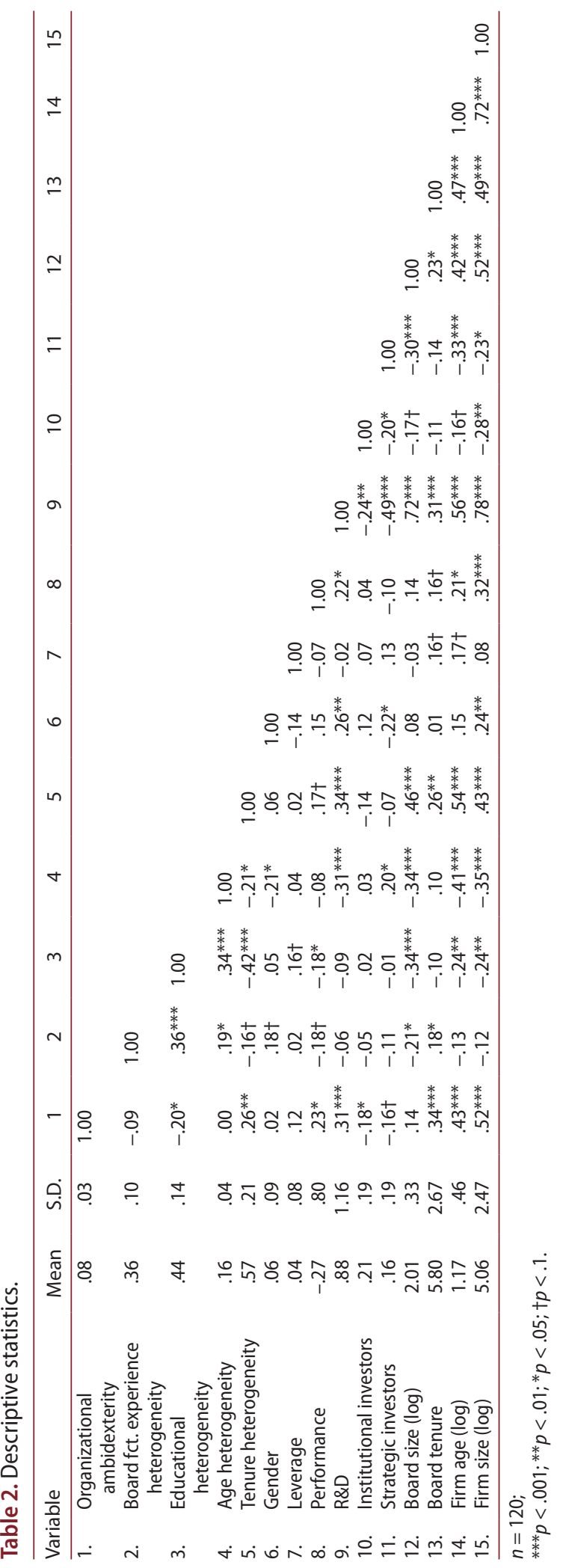


Table 3. GEE regression results.

\begin{tabular}{|c|c|c|}
\hline & Model 1 & Model 2 \\
\hline Method & GEE & GEE \\
\hline Dependent variable & Organizational ambidexterity & Organizational ambidexterity \\
\hline Constant & $\begin{array}{c}.083^{*} \\
(.036)\end{array}$ & $\begin{array}{l}.166^{* * *} \\
(.036)\end{array}$ \\
\hline Board fct. experience heterogeneity & $\begin{array}{l}-.029 \\
(.022)\end{array}$ & $\begin{array}{l}-.316^{* *} \\
(.100)\end{array}$ \\
\hline Board fct. experience heterogeneity (sqr) & & $\begin{array}{l}.347^{* *} \\
(.125)\end{array}$ \\
\hline Educational heterogeneity & $\begin{array}{l}-.030 \\
(.019)\end{array}$ & $\begin{array}{r}-.049^{*} \\
(.021)\end{array}$ \\
\hline Age heterogeneity & $\begin{array}{l}.170^{* *} \\
(.058)\end{array}$ & $\begin{array}{l}.182^{* * *} \\
(.055)\end{array}$ \\
\hline Tenure heterogeneity & $\begin{array}{l}.009 \\
(.009)\end{array}$ & $\begin{array}{l}.006 \\
(.008)\end{array}$ \\
\hline Gender & $\begin{array}{l}-.020 \\
(.032)\end{array}$ & $\begin{array}{l}-.030 \\
(.033)\end{array}$ \\
\hline Leverage & $\begin{array}{l}.034^{*} \\
(.014)\end{array}$ & $\begin{array}{l}.049^{* *} \\
(.016)\end{array}$ \\
\hline Performance & $\begin{array}{l}.003 \\
(.003)\end{array}$ & $\begin{array}{l}.004 \\
(.003)\end{array}$ \\
\hline$R \& D$ & $\begin{array}{c}-.004 \\
(.005)\end{array}$ & $\begin{array}{c}-.002 \\
(.005)\end{array}$ \\
\hline Institutional investors & $\begin{array}{l}-.013 \\
(.015)\end{array}$ & $\begin{array}{c}-.011 \\
(.016)\end{array}$ \\
\hline Strategic investors & $\begin{array}{l}-.040^{* *} \\
(.013)\end{array}$ & $\begin{array}{l}-.051^{* * *} \\
(.012)\end{array}$ \\
\hline Board size (log) & $\begin{array}{l}-.016 \\
(.013)\end{array}$ & $\begin{array}{l}-.024^{*} \\
(.011)\end{array}$ \\
\hline Board tenure & $\begin{array}{c}-.001 \\
(.001)\end{array}$ & $\begin{array}{c}-.001 \\
(.001)\end{array}$ \\
\hline Firm age $(\log )$ & $\begin{array}{c}-.002 \\
(.007)\end{array}$ & $\begin{array}{l}-.007 \\
(.006)\end{array}$ \\
\hline Firm size (log) & $\begin{array}{l}.008^{* * * *} \\
(.002)\end{array}$ & $\begin{array}{l}.008^{* * *} \\
(.002)\end{array}$ \\
\hline
\end{tabular}

Note: $n=120$ firm-years. Standard errors in parentheses; time effects are included but not reported. ${ }^{* * *} p<.001 ;{ }^{* *} p<.01 ;{ }^{*} p<.05 ; \dagger p<.1$.

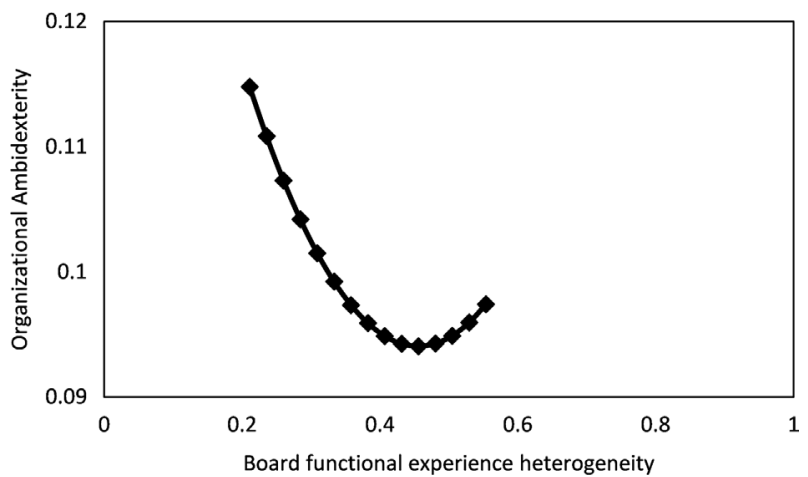

Figure 1. Effect of board functional experience heterogeneity on organizational ambidexterity.

of arguments, we hypothesized a U-shaped association between board knowledge heterogeneity and OA. However, the benefits of knowledge heterogeneity for OA only start outweighing the costs for boards that are highly heterogeneous. This 
implies that bringing boards and their characteristics into the dialog on OA is important, especially in KIFs, as the literature on OA is incomplete if it does not take into account the group of strategic leaders who shape strategic priorities and are ultimately held accountable for its outcomes. Our theory and findings have several implications for theory and practice.

\section{Contributions and implications}

\section{Organizational learning strategies in KIFs}

First, we contribute to the literature on organizational learning in KIFs. We argued for the need of balancing exploration and exploitation as a fundamental requirement for KIFs to remain globally competitive. We argued that given the importance of learning for KIFs, OA needs to be embedded at the highest level of strategy. As the board of directors shapes firm strategy through the tacit knowledge resource they provide (Heyden, Oehmichen, et al., 2015), we theorized about benefits of knowledge provision and cost of knowledge coordination in defining an ambidextrous learning strategy for KIFs. Additionally, our study has implications for the strategic human resource management (SHRM) literature as it offers an integration of this literature with organizational learning in the context of KIFs (Sekiguchi, Bebenroth, \& Li, 2011). This addition to the literature bolsters a complementary stream of literature that is increasingly focused on knowledge management and knowledge sharing in SHRM (Foss, Minbaeva, Pedersen, \& Reinholt, 2009). Accordingly, our study also provides important insights for the recruitment and staffing stream of HR literature (see e.g. Collings \& Mellahi, 2009). Recent studies demonstrate the increasing interest of HR research for appointment and dismissal decisions at the top levels of a firm's hierarchy (see e.g. Hamori \& Kakarika, 2009; Oehmichen, Schult, \& Wolff, in press). With respect to the recruitment and appointment of directors, KIFs could benefit from a deliberate recruitment of directors with varied functional backgrounds.

\section{Strategic leadership antecedents of $O A$}

We contribute to $\mathrm{OA}$ research by introducing boards as an underrepresented group of strategic leaders. We especially inform scholars and practitioners about key boundary conditions to the resource provision role of boards in relation to OA in KIFs. The role of the board has remained largely unaddressed prior to this study. Addressing this omission is essential, as boards define the strategic scope of the firm and are held accountable for long-term outcomes (Sundaramurthy, Mahoney, \& Mahoney, 1997). Given the importance of OA for KIFs, they face a particular need to embed a learning focus that incorporates both exploration and exploitation at the highest level of strategy.

The extent to which boards embed a balance between exploration and exploitation is important because these strategies cascade throughout the organization to inform how contradictory forces are reconciled in a day-to-day realization 
of strategy. We address a pressing need to understand the role of these strategic leaders in influencing OA in KIFs. As such, our study also contributes to OA literature in a broader sense as recent studies called for a more comprehensive understanding of interrelated multilevel antecedents of OA (Andriopoulos \& Lewis, 2009; Bledow et al., 2009; Simsek, 2009), especially accounting for the board as an important microfoundation of OA (Bonesso, Gerli, \& Scapolan, 2014).

\section{Costs and benefits of board knowledge heterogeneity}

Our study contributes to research about the impact of group composition, knowledge heterogeneity of boards in particular, but also of decision-makers in general. With respect to board heterogeneity we inform a field of SHRM that has largely overlooked the role of boards (Sanchez-Marin, Baixauli-Soler, \& LucasPerez, 2010; Wang \& Chiu, 2013). This is despite the fact that some scholars have argued that 'the board of directors is an important mechanism in determining a firm's strategies and aligning the interests of insiders, controlling shareholders and minority shareholders' (Mínguez-Vera \& Martin, 2011, p. 2852). There is consensus that heterogeneity within boards generally matters (e.g. Mínguez-Vera \& Martin, 2011; Triana et al., 2014). However, our study integrates the potential upsides and costs of board heterogeneity. Understanding when we can expect the benefits of heterogeneity to outweigh the costs enriches the SHRM literature concerned with heterogeneity (e.g. Ng \& Tung, 1998; Richard, Ford, \& Ismail, 2006; Zoogah et al., 2011).

\section{Boards of directors and strategy}

Directors are increasingly held accountable for outcomes of strategy (Aguilera, 2005; Huse, 2005; Oehmichen, Schrapp, \& Wolff, 2016; Roberts, McNulty, \& Stiles, 2005). The increasingly important role of boards in strategy making is illustrated by recent studies stressing that inadequate governance and resource provisioning of directors can result in inefficient decision-making processes and low performance (Piekkari, Oxelheim, \& Randøy, 2015; Schmidt, 2015). Therefore, studies have recognized the increasing importance of heterogeneity in board characteristics for understanding their accountability and responsibilities in firm strategy (Hillman, Nicholson, \& Shropshire, 2008). However, the degree of involvement of boards in strategy has been shown to vary across different global settings (Filatotchev, Chahine, \& Bruton, in press). Notwithstanding the current variety in strategic roles of boards observed across the globe (Heyden, Oehmichen, et al., 2015), boards are progressively expected to be involved in strategy through active provision of knowledge resources (Hillman \& Dalziel, 2003), and are being increasingly held accountable for the quality and effectiveness of strategic decisions across the globe (Hendry \& Kiel, 2004; Oehmichen et al., 2016). Accordingly, scholarly and policy inquiries into the board-strategy link can be expected to be a crucial area of growth for the future. 


\section{Managerial implications}

Some managerial implication can also be drawn from our study. The tensions we have described have been variously described in organization and managerial literature as change versus preservation (Poole \& van de Ven, 1989), adaptation versus selection (Lewin \& Volberda, 1999), adaptability versus alignment (Gibson \& Birkinshaw, 2004), and exploration versus exploitation (Jansen et al., 2009; March, 1991). Striking a balance between these tensions remains one of the most fundamental problems for strategically leading KIFs. One recommendation would be to systematically chart the tacit knowledge of the board to consider how new appointments can influence the collective knowledge heterogeneity of the group. Therefore, this study has important implications for director selection, since it demonstrates that varying functional expertise should become a more important criteria used during appointment. An actionable intervention when this is not immediately feasible could be for low-to moderately heterogeneous teams to draw on knowledge from outsiders, such as independent advisors, to help put different options into perspective and help synthesize polarized viewpoints (Alexiev, Jansen, Van den Bosch, \& Volberda, 2010; Heyden et al., 2013).

\section{Limitations and future research}

Our study is prone to several limitations that can pave the way for future research. First, we focus on boards with the underlying assumption that boards participate in shaping strategy, however, some studies show that this is not the case in all global contexts (Heyden, Oehmichen, et al., 2015). To maintain a tightly focused study, we did not include the role of other important strategic leaders such as executives and middle managers. Future research hence might want to respond to the general call for multilevel investigations in HRM research (e.g. Day \& Harrison, 2007; Snape \& Redman, 2010) and consider the effects of multilevel heterogeneity on OA and also investigate the impact of cross-level interaction. It might be feasible that the effects of heterogeneity on different hierarchical levels might substitute or complement one another (Heyden, Sidhu, et al., in press). Future research might want to test if our trade-off of knowledge provision and knowledge coordination costs caused by heterogeneity can also be observed at hierarchical levels other than the board and in other heterogeneity dimensions.

For example, a promising avenue for future research is to investigate how cultural differences among board members enhance or hinder the ability of a functionally diverse board to influence OA. Indeed, scholars have long argued that cultural differences significantly affect the way through which directors communicate and interact (Greve, Biemann, \& Ruigrok, 2015; Piekkari et al., 2015), or even how executive members benefit from diverse international career experience and knowledge from a variety of countries (Georgakakis, Dauth, \& Ruigrok, 2016; Georgakakis \& Ruigrok, in press). Assessing the impact of cultural diversity on 
the effect of boards on OA can therefore provide implications that are relevant for the broader field of strategy and international management.

Finally, there could be other contingencies that determine how board knowledge and diverse functional expertise influence OA. Scholars have recently stressed role of institutional context for the effectiveness of boards (Oehmichen et al., 2016) and for determining the role and impact of the board of directors (Filatotchev et al., in press; Ruigrok \& Georgakakis, 2012; Yoshikawa, Zhu, \& Wang, 2014). The role of boards in appointing and dismissing key executives (see e.g. Flickinger, Wrage, Tuschke, \& Bresser, 2016; Georgakakis \& Ruigrok, in press) to help execute ambidextrous strategies could also be further explored. In addition, although the board itself also plays a role as an internal governance mechanism, there is an increasing interest in external forms of governance that could influence the decisions made by strategic leaders (Aguilera, Desender, Bednar, \& Lee, 2015; Bednar, 2012; Heyden, Kavadis, \& Neuman, 2014), ultimately highlighting other pressures that may lead firms to over-explore or over-exploit.

In this study, we focused on pharmaceutical companies based in the UK, and therefore, our findings cannot necessarily be generalized to firms in countries with other corporate governance arrangement or board models (Heyden, Oehmichen, et al., 2015). In addition, we did not focus on the heterogeneous pathways and career experiences through which directors accumulate their tacit expertise and their abilities to become valuable contributors to the board (Georgakakis et al., 2016). Future research should further follow the call for multi-country corporate governance research (e.g. Aguilera \& Jackson, 2003; Hüttenbrink, Oehmichen, Rapp, \& Wolff, 2014) and therefore adopt multi-country samples beyond the UK to look into the effect of SHRM mechanisms such as compensation or high performance work systems to help extract the value, while minimizing the costs, of heterogeneous groups of strategic leaders. Finally, future studies could also consider looking separately at different dimensions of exploration and exploitation decisions (Nielsen \& Gudergan, 2012; Sidhu, Commandeur, \& Volberda, 2007; Stettner \& Lavie, 2014).

\section{Acknowledgments}

We would like to thank the guest editors for their editorial guidance and two anonymous reviewers for their constructive feedback throughout the review process.

\section{Disclosure statement}

No potential conflict of interest was reported by the authors.

\section{References}

Abor, J., Graham, M., \& Yawson, A. (2011). Corporate governance and restructuring activities following completed bids. Corporate Governance: An International Review, 19, 61-76. doi:10.1111/j.1467-8683.2010.00833.x 
Aguilera, R. V. (2005). Corporate governance and director accountability: An institutional comparative perspective. British Journal of Management, 16, 39-53. doi:10.1111/j.14678551.2005.00446.x

Aguilera, R. V., \& Jackson, G. (2003). The cross-national diversity of corporate governance: Dimensions and determinants. Academy of Management Review, 28, 447-465. doi: $10.2307 / 30040732$

Aguilera, R. V., Desender, K., Bednar, M. K., \& Lee, J. H. (2015). Connecting the dots - Bringing external corporate governance into the corporate governance puzzle. The Academy of Management Annals, 9, 483-573. doi:10.1080/19416520.2015.1024503

Alexiev, A. S., Jansen, J. J. P., Van den Bosch, F. A. J., \& Volberda, H. W. (2010). Top management team advice seeking and exploratory innovation: The moderating role of TMT heterogeneity. Journal of Management Studies, 47, 1343-1364. doi:10.1111/j.1467-6486.2010.00919.x

Ali, M., Kulik, C. T., \& Metz, I. (2011). The gender diversity-performance relationship in services and manufacturing organizations. The International Journal of Human Resource Management, 22, 1464-1485. doi:10.1080/09585192.2011.561961

Alvesson, M. (1993). Organizations as rhetoric: Knowledge-intensive firms and the struggle with ambiguity. Journal of Management Studies, 30, 997-1015.

Alvesson, M. (2000). Social identity and the problem of loyalty in knowledge- intensive companies. Journal of Management Studies, 37, 1101-1124.

Andriopoulos, C., \& Lewis, M. W. (2009). Exploitation-exploration tensions and organizational ambidexterity: Managing paradoxes of innovation. Organization Science, 20, 696-717. doi:10.2307/25614688

Ballinger, G. A. (2004). Using generalized estimating equations for longitudinal data analysis. Organizational Research Methods, 7, 127-150. doi:10.1177/1094428104263672

Bechky, B. A. (2003). Sharing meaning across occupational communities: The transformation of understanding on a production floor. Organization Science, 14, 312-330. doi:10.1287/ orsc.14.3.312.15162

Bednar, M. K. (2012). Watchdog or lapdog? A behavioral view of the media as a corporate governance mechanism. Academy of Management Journal, 55, 131-150. doi:10.5465/ amj.2009.0862

Ben-Menahem, S. M., von Krogh, G., Erden, Z., \& Schneider, A. (2016). Coordinating knowledge creation in multidisciplinary teams: Evidence from early-stage drug discovery. Academy of Management Journal, 59, 1308-1338. doi:10.5465/amj.2013.1214

Ben-Oz, C., \& Greve, H. R. (2012). Short- and long-term performance feedback and absorptive capacity. Journal of Management, 41, 1827-1853. doi:10.1177/0149206312466148

Bezrukova, K., Jehn, K. A., Zanutto, E. L., \& Thatcher, S. M. B. (2009). Do workgroup faultlines help or hurt? A moderated model of faultlines, team identification, and group performance. Organization Science, 20, 35-50. doi:10.1287/orsc.1080.0379

Bledow, R., Frese, M., Anderson, N., Erez, M., \& Farr, J. (2009). A dialectic perspective on innovation: conflicting demands, multiple pathways, and ambidexterity. Industrial and Organizational Psychology, 2, 305-337. doi:10.1111/j.1754-9434.2009.01154.x

Bonesso, S., Gerli, F., \& Scapolan, A. (2014). The individual side of ambidexterity: Do individuals' perceptions match actual behaviors in reconciling the exploration and exploitation trade-off? European Management Journal, 32, 392-405. doi:10.1016/j.emj.2013.07.003

Boulding, W., Morgan, R., \& Staelin, R. (1997). Pulling the plug to stop the new product drain. Journal of Marketing Research, 34, 164-176. doi:10.2307/3152073

Boyd, B. K. (1990). Corporate linkages and organizational environment: A test of the resource dependence model. Strategic Management Journal, 11, 419-430. doi:10.1002/smj.4250110602

Burgelman, R. (1983). A process model of internal corporate venturing in a major diversified firm. Administrative Science Quarterly, 28, 223-244. 
Burgess, N., Strauss, K., Currie, G., \& Geoffrey, W. (2015). Organizational ambidexterity and the hybrid middle manager: The case of patient safety in UK hospital. Human Resource Management, 54, s87-s109. doi:10.1002/hrm

Cannella, A. A., Park, J., \& Lee, H.-U. (2008). Top management team functional background diversity and firm performance: Examining the roles of team member colocation and environmental uncertainty. Academy of Management Journal, 51, 768-784. doi:10.5465/ AMJ.2008.33665310

Cao, Q., Gedajlovic, E. R., \& Zhang, H. (2009). Unpacking organizational ambidexterity: Dimensions, contingencies, and synergistic effects. Organization Science, 20, 781-796. doi:10.1287/orsc. 1090.0426

Carlile, P. R. (2002). A pragmatic view of knowledge and boundaries. Organization Science, 13, 442-455. doi:10.1287/orsc.13.4.442.2953

Carlile, P. R. (2004). Transferring, translating, and transforming: An integrative framework for managing knowledge across boundaries. Organization Science, 15, 555-568. doi:10.1287/ orsc. 1040.0094

Chang, Y.-Y., \& Hughes, M. (2012). Drivers of innovation ambidexterity in small- to mediumsized firms. European Management Journal, 30(1), 1-17. doi:10.1016/j.emj.2011.08.003

Chatterjee, A., \& Hambrick, D. C. (2007). It's all about me: Narcissistic Chief Executive Officers and their effects on company strategy and performance. Administrative Science Quarterly, 52, 351-386.

Coff, R. W. (1999). How buyers cope with uncertainty when acquiring firms in knowledge-intensive industries: Caveat emptor. Organization Science, 10, 144-161. doi:10.1287/orsc.10.2.144

Cohen, S., \& Kaimenakis, N. (2007). Intellectual capital and corporate performance in knowledgeintensive SMEs. The Learning Organization, 14, 241-262. doi:10.1108/09696470710739417

Collings, D. G., \& Mellahi, K. (2009). Strategic talent management: A review and research agenda. Human Resource Management Review, 19, 304-313. doi:10.1016/j.hrmr.2009.04.001

Day, D. V., \& Harrison, M. M. (2007). A multilevel, identity-based approach to leadership development. Human Resource Management Review, 17, 360-373. doi:10.1016/ j.hrmr.2007.08.007

Diestre, L., Rajagopalan, N., \& Dutta, S. (2015). Constraints in acquiring and utilizing directors' experience: An empirical study of new-market entry in the pharmaceutical industry. Strategic Management Journal, 36, 339-359. doi:10.1002/smj

Dougherty, D. (1992). Interpretive barriers to successful product innovation in large firms. Organization Science, 3, 179-202. doi:10.1287/orsc.3.2.179

Filatotchev, I., Chahine, S., \& Bruton, G. D. (in press). Board interlocks and initial public offering performance in the United States and the United Kingdom: An institutional perspective. Journal of Management. Retrieved from http://jom.sagepub.com/content/ early/2016/01/27/0149206315621145.abstract. doi:10.1177/0149206315621145

Flickinger, M., Wrage, M., Tuschke, A., \& Bresser, R. (2016). How CEOs protect themselves against dismissal: A social status perspective. Strategic Management Journal, 37, 1107-1117. doi: $10.1002 / \mathrm{smj} .2382$

Forbes, D. P., \& Milliken, F. J. (1999). Cognition and corporate governance: Understanding boards of directors as strategic decision-making groups. Academy of Management Review, 24, 489-505. Retrieved from http://www.jstor.org/stable/259138

Foss, N. J., Minbaeva, D. B., Pedersen, T., \& Reinholt, M. (2009). Encouraging knowledge sharing among employees: How job design matters. Human Resource Management, 48, 871-893. doi:10.1002/hrm

Georgakakis, D., \& Ruigrok, W. (in press). CEO succession origin and firm performance: A multilevel study. Journal of Management Studies. Retrieved from http://onlinelibrary.wiley. com/doi/10.1111/joms.12194/full. doi:10.1111/joms.12194 
Georgakakis, D., Dauth, T., \& Ruigrok, W. (2016). Too much of a good thing: Does international experience variety accelerate or delay executives' career advancement? Journal of World Business, 51, 425-437. doi:10.1016/j.jwb.2015.11.008

Gibson, C. B., \& Birkinshaw, J. (2004). The antecedents, consequences, and mediating role of organizational ambidexterity. Academy of Management Journal, 47, 209-226. doi:10.2307/20159573

Goodstein, J., Gautam, K., \& Boeker, W. (1994). The effects of board size and diversity on strategic change. Strategic Management Journal, 15, 241-250. Retrieved from http:// onlinelibrary.wiley.com/doi/10.1002/smj.4250150305/abstract

Grant, R. M. (1996). Toward a knowledge-based theory of the firm. Strategic Management Journal, 17, 109-122. Retrieved from http://pinje.cbs.dk/en/content/download/115558/1563508/file/ Grant

Greve, P., Biemann, T., \& Ruigrok, W. (2015). Foreign executive appointments: A multilevel examination. Journal of World Business, 50, 674-686. doi:10.1016/j.jwb.2014.10.012

Haans, R. F. J., Pieters, C., \& He, Z.-L. (2016). Thinking about U: Theorizing and testing $\mathrm{U}$ - and inverted U-shaped relationships in strategy research. Strategic Management Journal, 37, 1177-1195. doi:10.1002/smj.2399

Hair, J. F., Anderson, R. E., Tatham, R. L., \& Black, W. C. (1998). Multivariate data analysis. Upper Saddle River, NJ: Prentice Hall.

Hambrick, D. C., \& Mason, P. A. (1984). Upper echelons: The organization as a reflection of its top managers. Academy of Management Review, 9, 193-206. Retrieved from http://www. jstor.org/stable/258434

Hambrick, D. C., Cho, T. S., \& Chen, M.-J. (1996). The influence of top management team heterogeneity on firms' competitive moves. Administrative Science Quarterly, 41, 659-684. doi:10.2307/2393871

Hamori, M., \& Kakarika, M. (2009). External labor market strategy and career success: CEO careers in Europe and the United States. Human Resource Management, 48, 355-378. doi:10.1002/hrm

Harrison, D. A., \& Klein, K. J. (2007). What's the difference? Diversity constructs as separation, variety, or disparity in organizations. Academy of Management Review, 32, 1199-1228. doi:10.5465/AMR.2007.26586096

Haynes, K. T., \& Hillman, A. J. (2010). The effect of board capital and CEO power on strategic change. Strategic Management Journal, 31, 1145-1163. doi:10.1002/smj.859

He, Z.-L., \& Wong, P.-K. (2004). Exploration vs. exploitation: An empirical test of the ambidexterity hypothesis. Organization Science, 15, 481-494. doi:10.1287/orsc.1040.0078

Heavey, C., \& Simsek, Z. (in press). Distributed cognition in top management teams and organizational ambidexterity: The influence of transactive memory systems. Journal of Management. Retrieved from http://jom.sagepub.com/content/ early/2014/08/19/0149206314545652.abstract. doi:10.1177/0149206314545652

Hendry, K. P., \& Kiel, G. C. (2004). The role of the board in firm strategy: Integrating agency and organisational control perspectives. Corporate Governance: An International Review, 12, 500-520. doi:10.1111/j.1467-8683.2004.00390.x

Hendry, K. P., Kiel, G. C., \& Nicholson, G. (2010). How boards strategise: A strategy as practice view. Long Range Planning, 43, 33-56. doi:10.1016/j.lrp.2009.09.005

Hess, A. M., \& Rothaermel, F. T. (2011). When are assets complementary? Star scientists, strategic alliances, and innovation in the pharmaceutical industry. Strategic Management Journal, 32, 895-909. doi:10.1002/smj.916

Heyden, M. L. M., Kavadis, N., \& Neuman, Q. (2014). External corporate governance and strategic investment behaviors of target CEOs. Journal of Management, XX, 1-25. $10.1177 / 0149206314563400$ 
Heyden, M. L. M., Oehmichen, J., Nichting, S., \& Volberda, H. W. (2015). Board background heterogeneity and exploration-exploitation: The role of the institutionally adopted board model. Global Strategy Journal, 5, 154-176. doi:10.1002/gsj.1095

Heyden, M. L. M., Sidhu, J. S., \& Volberda, H. W. (in press). The conjoint influence of top and middle management characteristics on management innovation. Journal of Management. Retrieved from http://jom.sagepub.com/content/early/2015/12/04/0149206315614373. abstract. doi:10.1177/0149206315614373

Heyden, M. L. M., van Doorn, S., Reimer, M., Van Den Bosch, F. A. J., \& Volberda, H. W. (2013). Perceived environmental dynamism, relative competitive performance, and top management team heterogeneity: Examining correlates of upper echelons' advice-seeking. Organization Studies, 34, 1327-1356. doi:10.1177/0170840612470229

Hillman, A. J., \& Dalziel, T. (2003). Boards of directors and firm performance: Integrating agency and resource dependence perspectives. Academy of Management Review, 28, 383396. doi: $10.2307 / 30040728$

Hillman, A. J., Nicholson, G., \& Shropshire, C. (2008). Directors' multiple identities, identification, and board monitoring and resource provision. Organization Science, 19, 441-456. doi:10.1287/orsc.1080.0355

Hoskisson, R. E., Johnson, R. A., \& Moesel, D. D. (1994). Corporate divestiture intensity in restructuring firms: Effects of governance, strategy, and performance. Academy of Management Journal, 37, 1207-1251. Retrieved from http://amj.aom.org/content/37/5/1207. short

Huse, M. (2005). Accountability and creating accountability: A framework for exploring behavioural perspectives of corporate governance. British Journal of Management, 16, S65-S79. doi:10.1111/j.1467-8551.2005.00448.x

Hüttenbrink, A., Oehmichen, J., Rapp, M. S., \& Wolff, M. (2014). Pay-for-performance - Does one size fit all? A multi-country study of Europe and the United States. International Business Review, 23, 1179-1192. doi:10.1016/j.ibusrev.2014.04.002

Jackson, S. E. (1992). Consequences of group composition for the interpersonal dynamics of strategic issue processing. Advances in Strategic Management, 8, 345-382. Retrieved from http://scholar.google.com/scholar?hl=en\&btnG=Search\&q=intitle:CONSEQUENCES+ $\mathrm{OF}+\mathrm{GROUP}+\mathrm{COMPOSITION}+\mathrm{FOR}+\mathrm{THE}+\mathrm{INTERPERSONAL+DYNAMICS}+\mathrm{OF}+$ STRATEGIC+ISSUE+PROCESSING\#0

Jansen, J. J. P., George, G., Van Den Bosch, F. A. J., \& Volberda, H. W. (2008). Senior team attributes and organizational ambidexterity: The moderating role of transformational leadership. Journal of Management Studies, 45, 982-1007. doi:10.1111/j.1467-6486.2008.00775.x

Jansen, J. J. P., Tempelaar, M. P., Van den Bosch, F. A. J., \& Volberda, H. W. (2009). Structural differentiation and ambidexterity: The mediating role of integration mechanisms. Organization Science, 20, 797-811.

Jansen, J. J. P., Simsek, Z., \& Cao, Q. (2012). Ambidexterity and performance in multiunit contexts: Cross-level moderating effects of structural and resource attributes. Strategic Management Journal, 33, 1286-1303. doi:10.1002/smj

Jansen, J. J. P., Van den Bosch, F. A. J., \& Volberda, H. W. (2005). Exploratory innovation, exploitative innovation, and ambidexterity: The impact of environmental and organizational antecedents. Schmalenbach Business Review, 57, 351-363.

Jansen, J. J. P., van den Bosch, F., \& Volberda, H. W. (2006). Exploratory innovation, exploitative innovation, and performance: Effects of organizational and environmental moderators. Management Science, 52, 1661-1674. doi:10.1287/mnsc.1060.0576

Judge, W. Q., \& Miller, A. (1991). Antecedents and outcomes of decision speed in different envirnmental contexts. Academy of Management Journal, 34, 449-463. doi: $10.2307 / 256451$ 
Khanna, R., Guler, I., \& Nerkar, A. (2016). Fail often, fail big, and fail fast? Learning from small failures and R\&D performance in the pharmaceutical industry. Academy of Management Journal, 59, 436-459. doi:10.5465/amj.2013.1109

Knight, D., Pearce, C. L., Smith, K. G., Olian, J. D., Sims, H. P., Smith, K. A., \& Flood, P. (1999). Top management team diversity, group process, and strategic consensus. Strategic Management Journal, 20, 445-465. doi:10.1002/(SICI)1097-0266(199905)20:5<445:AIDSMJ27>3.0.CO;2-V

Lau, D. C., \& Murnighan, J. K. (1998). Demographic diversity and faultlines: The compositional dynamics of groups. Academy of Management Journal, 23, 325-340.

Levinthal, D. A., \& March, J. G. (1993). The myopia of learning. Strategic Management Journal, 14, 95-112. doi:10.1002/smj.4250141009

Lewin, A. Y., \& Volberda, H. W. (1999). Prolegomena on coevolution: A framework for research on strategy and new organizational forms. Organization Science, 10, 519-534. doi:10.1287/ orsc.10.5.519

Lieberman, M. B., \& Asaba, S. (2006). WHY do firms imitate each other? Academy of Management Review, 31, 366-385. doi:10.5465/AMR.2006.20208686

Lungeanu, R., Stern, I., \& Zajac, E. J. (2016). When do firms change technology-sourcing vehicles?. The role of poor innovative performance and financial slack. Strategic Management Journal, 37, 855-869. doi:10.1002/smj.2371

Luo, Y., Sun, J., Lu Wang, S., Yadong, L., Jinyun, S., \& Lu Wang, S. (2011). Emerging economy copycats: Capability, environment, and strategy. Academy of Management Perspectives, 25, 37-56. doi:10.5465/AMP.2011.61020801

Majchrzak, A., More, P. H. B., \& Faraj, S. (2012). Transcending knowledge differences in crossfunctional teams. Organization Science, 23, 951-970. doi:10.1287/orsc.1110.0677

March, J. G. (1991). Exploration and exploitation in organizational learning. Organization Science, 2, 71-87.

Maslach, D. (2016). Change and persitence with failed technological innovation. Strategic Management Journal, 37, 714-723. doi:10.1002/smj.2358

McDonald, M. L., Westphal, J. D., \& Graebner, M. E. (2008). What do they know? The effects of outside director acquisition experience on firm acquisition performance. Strategic Management Journal, 29, 1155-1177. doi:10.1002/smj

Mell, J. N., van Knippenberg, D., \& van Ginkel, W. P. (2014). The catalyst effect: The impact of transactive memory system structure on team performance. Academy of Management Journal, 57, 1154-1173. doi:10.5465/amj.2012.0589

Milliken, F. J., \& Martins, L. L. (1996). Searching for common threads: Understanding the multiple effects of diversity in organizational groups. Academy of Management Review, 21, 402-433. doi:10.5465/AMR.1996.9605060217

Mínguez-Vera, A., \& Martin, A. (2011). Gender and management on Spanish SMEs: An empirical analysis. The International Journal of Human Resource Management, 22, 28522873. doi:10.1080/09585192.2011.599948

Minichilli, A., Zattoni, A., \& Zona, F. (2009). Making boards effective: An empirical examination of board task performance. British Journal of Management, 20, 55-74. doi:10.1111/j.14678551.2008.00591.x

Mom, T. J. M., Fourné, S. P. L., \& Jansen, J. J. P. (2015). Managers' work experience, ambidexterity, and performance: The contingency role of the work context. Human Resource Management, 54 (S1), s133-s153. doi:10.1002/hrm.21663

Mom, T. J. M., Van den Bosch, F. A. J., \& Volberda, H. W. (2007). Investigating managers' exploration and exploitation activities: The influence of top-down, bottom-up, and horizontal knowledge inflows. Journal of Management Studies, 44, 910-931. doi:10.1111/ j.1467-6486.2007.00697.x 
Mom, T. J. M., Van den Bosch, F. A. J., \& Volberda, H. W. (2009). Understanding variation in managers' ambidexterity: Investigating direct and interaction effects of formal structural and personal coordination mechanisms. Organization Science, 20, 812-828. doi:10.1287/ orsc. 1090.0427

Ng, E. S. W., \& Tung, R. L. (1998). Ethno-cultural diversity and organizational effectiveness: A field study. The International Journal of Human Resource Management, 9, 980-995. doi:10.1080/095851998340702

Nielsen, B. B., \& Gudergan, S. (2012). Exploration and exploitation fit and performance in international strategic alliances. International Business Review, 21, 558-574. doi:10.1016/ j.ibusrev.2011.07.001

Nielsen, B. B., \& Nielsen, S. (2013). Top management team nationality diversity and firm performance: A multilevel study. Strategic Management Journal, 34, 373-382. doi:10.1002/smj

O’Reilly, C. A., \& Tushman, M. L. (2013). Organizational ambidextiry: Past, present, and future. Academy of Management Perspectives, 27, 324-338. doi:10.5465/amp.2013.0025

Oehmichen, J., Schrapp, S., \& Wolff, M. (in press). Who needs experts most? Board industry expertise and strategic change - A contingency perspective. Strategic Management Journal. Retrieved from http://onlinelibrary.wiley.com/doi/10.1002/smj.2513/full. doi:10.1002/ smj. 2513

Oehmichen, J., Schult, A., \& Wolff, M. (in press). Keeping their cards close to their chests: How non-delegating CEOs avoid forced career ends. Human Resource Management. Retrieved from http://onlinelibrary.wiley.com/doi/10.1002/hrm.21732/full. doi:10.1002/hrm.21732

Pan, W. (2001). Akaike's information criterion in generalized estimating equations. Biometrics, 57, 120-125.

Piao, M. (2010). Thriving in the new: Implication of exploration on organizational longevity. Journal of Management, 36, 1529-1554. doi:10.1177/0149206310378367

Piekkari, R., Oxelheim, L., \& Randøy, T. (2015). The silent board: How language diversity may influence the work processes of corporate boards. Corporate Governance: An International Review, 23, 25-41. doi:10.1111/corg.12085

Polanyi, M. (1966). The tacit dimension. London: Routledge and Kegan Paul.

Poole, M. S., \& van de Ven, A. H. (1989). Using paradox to build management and organization theories. Academy of Management Review, 14, 562-578. doi:10.2307/258559

Raisch, S., \& Birkinshaw, J. (2008). Organizational ambidexterity: Antecedents, outcomes, and moderators. Journal of Management, 34, 375-409. doi:10.1177/0149206308316058

Richard, O. C., Barnett, T., Dwyer, S., \& Chadwick, K. (2004). Cultural diversity in management, firm performance, and the moderating role of entrepreneurial orientation dimensions. Academy of Management Journal, 47, 255-266.

Richard, O. C., Ford, D., \& Ismail, K. (2006). Exploring the performance effects of visible attribute diversity: The moderating role of span of control and organizational life cycle. The International Journal of Human Resource Management, 17, 2091-2109. doi:10.1080/09585190601000246

Roberts, J., McNulty, T., \& Stiles, P. (2005). Beyond agency conceptions of the work of the nonexecutive director: Creating accountability in the boardroom. British Journal of Management, 16, S5-S26. doi:10.1111/j.1467-8551.2005.00444.x

Ruigrok, W., \& Georgakakis, D.(2012). Corporate governance and initial public offerings in Switzerland. In W. Q. Judge \& A. Zattoni (Eds.), Corporate governance and initial public offerings: An international perspective (pp. 449-469). Cambridge: Cambridge University Press. 10.1017/CBO9781139061513

Sanchez-Marin, G., Baixauli-Soler, J. S., \& Lucas-Perez, M. E. (2010). When much is not better? Top management compensation, board structure, and performance in Spanish firms. The International Journal of Human Resource Management, 21, 2778-2797. doi:10.1080/09585 192.2010.528660 
Schmidt, B. (2015). Costs and benefits of friendly boards during mergers and acquisitions. Journal of Financial Economics, 117, 424-447. doi:10.1016/j.jfineco.2015.02.007

Sekiguchi, T., Bebenroth, R., \& Li, D. (2011). Nationality background of MNC affiliates' top management and affiliate performance in Japan: Knowledge-based and upper echelons perspectives. The International Journal of Human Resource Management, 22, 999-1016. doi:10.1080/09585192.2011.556774

Sidhu, J. S., Commandeur, H. R., \& Volberda, H. W. (2007). The multifaceted nature of exploration and exploitation: Value of supply, demand, and spatial search for innovation. Organization Science, 18, 20-38. doi:10.1287/orsc.1060.0212

Simsek, Z. (2009). Organizational ambidexterity: Towards a multilevel understanding. Journal of Management Studies, 46, 597-624. doi:10.1111/j.1467-6486.2009.00828.x

Snape, E., \& Redman, T. (2010). HRM practices, organizational citizenship behaviour, and performance: A multi-level analysis. Journal of Management Studies, 47, 1219-1247. doi:10.1111/j.1467-6486.2009.00911.x

Starbuck, W. H. (1992). Learning by knowledge-intensive firms. Journal of Management Studies, $29,713-740$.

Sterman, J. D. (1989). Modeling managerial behavior: Misperceptions of feedback in a dynamic decision making experiment. Management Science, 35, 321-339. doi:10.1287/mnsc.35.3.321

Stettner, U., \& Lavie, D. (2014). Ambidexterity under scrutiny: Exploration and exploitation via internal organization, alliances, and acquisitions. Academy of Management Journal, 35, 1903-1929. doi:10.1002/smj

Sundaramurthy, C., Mahoney, J. M., \& Mahoney, J. T. (1997). Board structure, antitakeover provisions, and stockholder wealth. Strategic Management Journal, 18, 231-245. doi:10.1002/ (SICI) 1097-0266(199703)18:3<231:AID-SMJ877>3.3.CO;2-M

Swart, J., \& Kinnie, N. (2003a). Knowledge-intensive firms: The influence of the client on HR systems. Human Resource Management Journal, 13, 37-55.

Swart, J., \& Kinnie, N. (2003b). Sharing knowledge in knowledge-intensive firms. Human Resource Management Journal, 13, 60-75. doi:10.1111/j.1748-8583.2003.tb00091.x

Swart, J., Kinnie, N., van Rossenberg, Y., \& Yalabik, Z. Y. (2014). Why should I share my knowledge? A multiple foci of commitment perspective. Human Resource Management Journal, 24, 269-289. doi:10.1111/1748-8583.12037

Triana, C., Miller, T. L., \& Trzebiatowski, T. M. (2014). The double-edged nature of board gender diversity: Diversity, firm performance, and the power of women directors as predictors of strategic change. Organization Science, 25, 609-632.

Tuggle, C. S., Schnatterly, K., \& Johnson, R. A. (2010). Attention patterns in the boardroom: How board composition and processes affect discussion of entrepreneurial issues. Academy of Management Journal, 53, 550-571. Retrieved from http://aom.metapress.com/index/ Y05382818PU8X2M2.pdf

Turner, N., Swart, J., \& Maylor, H. (2013). Mechanisms for managing ambidexterity: A review and research agenda. International Journal of Management Reviews, 15, 317-332. doi:10.1111/j.1468-2370.2012.00343.x

Uotila, J., Maula, M., Keil, T., \& Zahra, S. A. (2009). Exploration, exploitation, and financial performance: Analysis of S\&P 500 corporations. Strategic Management Journal, 231, 221231.

van Ginkel, W. P., \& van Knippenberg, D. (2008). Group information elaboration and group decision making: The role of shared task representations. Organizational Behavior and Human Decision Processes, 105, 82-97. doi:10.1016/j.obhdp.2007.08.005

van Knippenberg, D., De Dreu, C. K. W., \& Homan, A. C. (2004). Work group diversity and group performance: An integrative model and research agenda. Journal of Applied Psychology, 89, 1008-1022. doi:10.1037/0021-9010.89.6.1008 
Vassolo, R. S., Anand, J., \& Folta, T. B. (2004). Non-additivity in portfolios of exploration activities: A real options-based analysis of equity alliances in biotechnology. Strategic Management Journal, 25, 1045-1061. doi:10.1002/smj.414

Vidal, E., \& Mitchell, W. (2015). Adding by subtracting: The relationship between performance feedback and resource reconfiguration through divestitures. Organization Science, 26, 11011118. doi:10.1287/orsc.2015.0981

Volberda, H. W., Baden-Fuller, C., \& Van den Bosch, F. A. J. (2001). Mastering strategic renewal: Mobilising renewal journeys in multi-unit firms. Long Range Planning, 34, 159-178. Retrieved from http://www.sciencedirect.com/science/article/pii/S0024630101000322

Von Nordenflycht, A. (2010). What is a professional service firm? Toward a theory and taxonomy of knowledge-intensive firms Academy of Management Review, 35, 155-174. Retrieved from http://doi.org/ $<$ spanrwTHpgen="1" $>10.5465 /$ AMR.2010. $</$ span $><$ strong $>45577926$ $</$ strong $>$

Walrave, B., van Oorschot, K. E., \& Romme, A. G. L. (2011). Getting trapped in the suppression of exploration: A simulation model. Journal of Management Studies, 48, 1727-1751. doi:10.1111/j.1467-6486.2011.01019.x

Wang, M.-C., \& Chiu, S.-T. (2013). The function of independent directors with different payoff rules: The issue of shareholder activism. The International Journal of Human Resource Management, 24, 3020-3030. doi:10.1080/09585192.2013.767063

Wang, H., \& Li, J. (2008). Untangling the effects of overexploration and overexploitation on organizational performance: The moderating role of environmental dynamism. Journal of Management, 34, 925-951. doi:10.1177/0149206308321547

Yawson, A. (2006). Evaluating the characteristics of corporate boards associated with layoff decisions. Corporate Governance: An International Review, 14, 75-84. doi:10.1111/j.14678683.2006.00488.x

Yitzhack Halevi, M., Carmeli, A., \& Brueller, N. N. (2015). Ambidexterity in SBUs: TMT behavioral integration and environmental dynamism. Human Resource Management, 54, s223-s238. doi:10.1002/hrm.21665

Yoshikawa, T., Zhu, H., \& Wang, P. (2014). National governance system, corporate ownership, and roles of outside directors: A corporate governance bundle perspective. Corporate Governance: An International Review, 22, 252-265. doi:10.1111/corg.12050

Zhang, Z.-X., Hempel, P. S., Han, Y.-L., \& Tjosvold, D. (2007). Transactive memory system links work team characteristics and performance. Journal of Applied Psychology, 92, 1722-1730. doi:10.1037/0021-9010.92.6.1722

Zoogah, D. B., Vora, D., Richard, O., \& Peng, M. W. (2011). Strategic alliance team diversity, coordination, and effectiveness. The International Journal of Human Resource Management, 22, 510-529. doi:10.1080/09585192.2011.543629 